\title{
Application of Energy-saving New Materials in Construction Engineering
}

\author{
Qi Zhang ${ }^{1}$ \\ ${ }^{1}$ Dalian Vocational \&Technical College（DaLian Radio and TV University） Dalian,Liaoning Province,116035
}

\begin{abstract}
Energy-saving new materials and new technologies are conducive to energy conservation. Alleviating the current energy crisis we need to face will help improve the quality of life of the people. In this article, the author mainly discusses the application of new energy-saving materials in construction engineering.
\end{abstract}

\section{Introduction}

In recent years, we have been committed to researching new building materials and new technologies, hoping to help us through the energy crisis through these energy-saving materials. In addition, in terms of the current development of China's construction industry, it is very necessary to use some energy-saving new materials and new technologies. China's construction industry has developed very rapidly in recent years, but this development is based on high energy consumption. According to survey data, it can be shown that China currently has an average of 2 billion square meters of buildings under development each year, but at the same time, the energy consumption of buildings also accounts for $27.5 \%$ of the total energy consumption of society. Whether it is from the perspective of product composition or overall process, the current development of energy-saving materials and energy-saving technologies in China still has a certain gap with developed countries. Currently, China is discussing how to improve the energy efficiency of buildings. However, foreign countries have already considered how to reduce carbon dioxide emissions and reduce the greenhouse effect. When China is discussing how to study energy-saving materials, foreign countries have already discussed how to promote energy-saving materials to the world, so we still have a very long way to go.

\section{Energy-saving New Materials and New Technologies}

If we want to reduce the energy consumption of buildings, then we must consider the energy efficiency of buildings. What we mean by building energy efficiency actually refers to the selection of new materials and new technologies in the planning and design process of the building on the premise of satisfying people's normal life, so that the construction process of the building can achieve low energy consumption. purpose. Reasonably design the thermal performance of the building, effectively improve the operating efficiency of heating, ventilation and piping systems, reduce energy consumption, and use some renewable energy more scientifically, which can effectively improve the comfort of the building and realize the energy saving of the building. Simply put, it is to use the least energy to make people live a more comfortable life. Generally speaking, new energy-saving materials are different from traditional bricks and tiles. This is a new type of building material with a very rich variety. If classified in terms of function, new energy-saving materials can be divided into wall materials, decorative materials, thermal insulation materials and so on. From the material point of view, energy-saving new materials can also be divided into natural materials and chemical materials, and so on. To a certain extent, the use of new energy-saving materials can help us alleviate the current energy crisis and improve people's production and life. First of all, the development and utilization of new energy-saving materials have effectively alleviated the energy shortage. Secondly, new energy-saving materials can replace traditional bricks and tiles, which can effectively reduce carbon dioxide and acid gas emissions. Finally, with the continuous improvement of China's construction level, people have higher and higher requirements for environmental protection, and a healthy and comfortable environment has now become a major pursuit of people.

\section{The Significance of Using Environmentally Friendly Building Materials}

From the perspective of China's current development of the construction industry, the use of environmentally friendly building materials is an inevitable development of the times. The main practical significance of using 
environmentally friendly building materials in building materials can be summarized as follows. The first point is that the use of environmentally friendly building materials is of great significance for absorbing advanced foreign construction experience. China has always been very supportive of using some environmentally friendly materials in construction. There are still vacancies in China's research on environmentally friendly materials. We can actively learn from foreign experience to a certain extent, and then create opportunities to promote the development of environmentally friendly building materials in China. The second point is that the use of environmentally friendly materials can promote the production of new technologies and new materials. The use of environmentally friendly building materials is not very widespread at present, and we still use some traditional building materials in our construction. Environmentally friendly materials cannot only exist in the laboratory. We must use them widely before we can truly understand the rationality and scientific nature of the materials, so as to effectively promote the production of new materials and technologies.

\section{New Energy-saving Materials}

\subsection{Thermal Insulation Mortar}

The main materials of thermal insulation mortar are cement and expanded perlite. Insulation mortar is based on its raw materials, adding some additives such as cellulose to make it a composite insulation material. Insulation mortar has very high strength and is not easy to burn. Its thermal conductivity is relatively low, and its thermal insulation performance is very good. Moreover, its cost price is not high, and it has very good cohesion after adding water and stirring, and it is easier to construct. In summer, the room temperature of the house with wall treatment is 2 to $3^{\circ} \mathrm{C}$ lower than that of the untreated house. Insulation mortar can effectively help the air-conditioning in the building to save about $15 \%$. The annual air-conditioning operation time can also be shortened by about 20 days. Thermal insulation mortar is an ideal energy-saving material in hot summer and cold winter areas. It can effectively keep heat insulation and belongs to a new generation of green environmental protection materials.

\subsection{Polystyrene Foam Board}

According to the molding process, polystyrene foam board can be divided into two types, namely Eps and Xps. After the polystyrene foam board is heated, it needs to be heated and formed in the mold. It has the characteristics of fine closed cell structure, because it can effectively heat the roof, so it is mainly used in the wall. Besides, polystyrene foam panels are also used in cold storage and vehicle insulation. In addition, polystyrene foam board can also be used in floor heating, so this foam board has a wide range of uses.

\subsection{Rigid Polyurethane Waterproof Insulation Material}

Polyurethane insulation composite board is made of two layers of water-proof steel plate or other metal plates as the panel, and polyurethane rigid foam is injected in the middle. Rigid polyurethane waterproof and thermal insulation material is now recognized as the best thermal insulation material in the world, and it is often used in large-scale factories or exhibition halls and cold storage. This composite board can not only keep heat and heat insulation, but also waterproof. Moreover, its color is relatively rich, its shape is very beautiful, its own weight is relatively light, and its carrying capacity is very strong. Meanwhile, its fire resistance and thermal insulation performance are very good, and it is more flexible to use.

\section{The Use of New Materials in Building Energy Efficiency}

\subsection{New Energy-saving Wall}

There are many varieties of new wall materials. In terms of current applications, the proportion of new wall materials used in all wall materials has become higher and higher. The new wall materials mainly include three types of bricks, blocks and boards. For example, clay hollow bricks, non-clay bricks, aerated concrete lightweight panels, etc. are all new wall materials. As far as the current development of the construction industry is concerned, all regions need to develop energy-saving walls according to local conditions according to actual and specific development conditions. The energy saving and environmental protection of the wall is completed by changing the structure of the materials used in the wall. In the field of energy-saving wall development, European and American countries have developed very well. As a result, we can learn from it appropriately. At present, the output of new wall materials in European and American countries has stabilized, and the technology has also begun to develop in the direction of large holes. In addition, the bulk density of aerated concrete abroad is generally 400 to 500 kilograms, and the bulk density of non-load-bearing products has dropped to 300 kilograms per cubic meter. Moreover, the raw materials of foreign aerated concrete mostly use industrial waste. Furthermore, some other new materials such as STP external insulation boards, fly ash bricks and other new materials have also been widely used in the construction market.

\subsection{Application of Energy-saving Doors and Windows}

Doors and windows are very important to buildings, because doors and windows are a main channel connecting the inside and outside of the building, which can realize daily energy exchange, so the energy saving of doors and windows is of great significance to the overall building. In addition to improving the thermal performance of the glass itself, the energy saving of 
doors and windows should also use insulating glass to ensure the airtightness of the glass. In addition, we should also start with the tightness of the joints between the glass and the frame and the overlap joints of doors and windows to ensure that the tightness of all parts can effectively ensure the reduction of air circulation. From the perspective of craftsmanship and materials, the energy-saving of doors and windows must be done with the construction process of reserved openings during installation. It is strictly forbidden to build the joints while installing, or to build the joints after installation. When welding, we need to select the welding process according to the different materials of the doors and windows. No matter which welding method is adopted, we must ensure the firmness of the installation of doors and windows. When designing, we should try our best to increase the overlap of the opening gap and reduce the gap width. In the meantime, we should also select the sealing strip according to the material of the door and window, and seal it to ensure the intimacy of the outer window. While ensuring sufficient space for metal framed doors and windows, we should also use heat-insulating materials such as plastic or rubber to treat them. We should effectively ensure the length and width of the broken bridge. When installing other accessories, never destroy the broken bridge. Polystyrene board or polyurethane material is used at the position where the outer doors and windows are connected to the wall. We cannot use cement mortar, which can effectively ensure the tightness around the outer doors and windows.

\subsection{Application of Energy-saving Roof}

Generally speaking, roof insulation is a kind of insulation material with lower bulk density, lower thermal conductivity, lower water absorption, and certain strength. If the roof is laid in this way, we can choose some insulation materials like slab-shaped aerated concrete blocks, cement or asphalt perlite slabs. We can use bulk materials and cement and other cementing materials for on-site pouring, including ceramsite, perlite, pumice and other methods. Otherwise, we can also use loose materials or bagged glass wool, waste polystyrene particles and so on. On-site foaming and pouring include rigid polyester foam and cement-based foam concrete, etc. The reverse laying method is mainly to put the waterproof layer under the insulation layer, which can effectively protect the waterproof layer and facilitate the maintenance of the staff. However, the cost of this method is relatively high, so we have not yet used this method of construction in residential buildings.

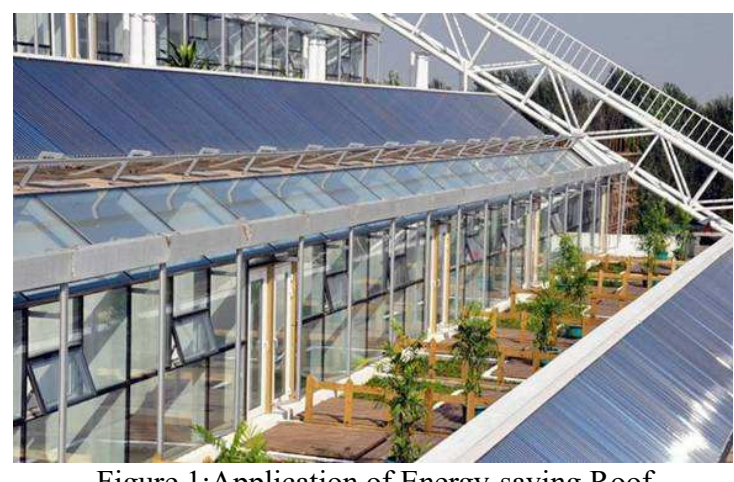

Figure 1:Application of Energy-saving Roof

\section{Waterproof Sealing Material}

\subsection{Waterproof Materials}

Waterproof membranes mainly include asphalt membranes and polymer waterproof membranes. In construction projects, most of what we use are polymer modified asphalt coils. First of all, this kind of asphalt roll material effectively improves the high temperature resistance of traditional asphalt, increases its low temperature elasticity, and improves the construction method. Secondly, this kind of asphalt membrane also expands the temperature range of the waterproof membrane, and at the same time effectively improves the strength of the asphalt and the aging resistance of the membrane, and extends the service life of the waterproof membrane. Third, the polymer coil has relatively high strength, good extensibility, and very good high and low temperature performance. We can use single-layer cold bonding method for construction. Fourth, this kind of coil material effectively improves the construction environment and improves the construction quality of the entire project.

\subsection{Waterproof Coating}

The waterproof coating can be fluid or viscous liquid before use, and it can be cured on site to form a seamless waterproof layer. Compared with waterproof membrane, waterproof coating has better waterproof performance. The waterproof coating not only has a relatively high degree of connection, but also has a very good temperature adaptability and high flexibility during construction. This can effectively increase the construction speed of workers and facilitate maintenance.

\section{Application of Solar Building Technology}

In our daily life, solar energy has always been the cleanest and most abundant energy source. Nowadays, solar energy has been widely used in China's construction process. The environmental protection and energy saving of solar energy can be reflected in many aspects of buildings. For example, installing a solar power system on the roof of a building can collect the light radiated by the sun into solar cells, and then convert 
it into electrical energy. The electrical energy is stored by the battery and connected to the corresponding power supply facilities, which can basically satisfy the whole power demand of the building and the electricity consumption of the lighting system. Solar heating and heating functions have been used in my country for a long time. Solar energy resources are relatively abundant, which can well meet the daily work needs of buildings. In addition, solar energy technology can also control the lighting of buildings, which is conducive to the daily energy saving of buildings. Solar energy is a kind of abundant and clean energy. It is safe and reliable to use in buildings without any pollution. Simultaneously, it does not consume any fuel, is not restricted by the environment, and is very simple to maintain and easy to install. Solar energy is the most suitable technology for building energy saving and environmental protection.

When choosing the application of solar building technology, we can also adapt it to local conditions according to the different climate characteristics of different regions in China. For example, in northern China, the winter in the north is relatively cold, so we must effectively improve the thermal performance of buildings, give play to the heat source effect of buildings, take certain measures to reduce heating energy consumption, and actively improve heating equipment . However, for cities in the south, there are more humid weather in the south. In consequence, we must improve the building's natural ventilation and shading technology to effectively reduce the building's energy consumption. This can not only achieve the effect of environmental protection, but also effectively ensure the normal use of the building.

\section{Conclusion}

All in all, in the future we will definitely face the situation of architectural modernization. As a consequence, we must also stick to the path of sustainable development and choose some advanced energy-saving buildings that suit China's national conditions. This is a step we must take. In the process of urban development in China, the building energy efficiency industry has great development potential, and it can be said that the prospects are very bright. Promoting building energy conservation and using some new energy-saving materials can create a healthier, more comfortable, and more beautiful home for us. This is also our common responsibility. In the future, as long as we actively create a building energy-saving atmosphere and consciously participate in the ranks of energy-saving, we will certainly be able to further develop building energy-saving technologies and enable more citizens to obtain more benefits from energy-saving buildings.

\section{References:}

1. Zou Zhixin, $\mathrm{Xu}$ Shuilin. Application of new energy-saving materials in construction projects[J]. Urban Construction Theory Research (Electronic Edition), 2013, (15).
2. Shi Xichen. Application of new energy-saving materials in construction engineering $[\mathrm{J}]$. Construction Engineering Technology and Design, 2019, (11): 3798.

3. Gao Hui. Application of new energy-saving materials in construction projects[J]. Urban Construction Theoretical Research (Electronic Edition), 2012, (35).

4. Li Yuntong. Application of new energy-saving materials in construction engineering $[\mathrm{J}]$. Construction Engineering Technology and Design, 2018, (13): 4561.

5. Li Xinchao. Application of new energy-saving materials in construction projects[J]. Urban Construction Theory Research (Electronic Edition), 2013, (6).

6. Wang Wei. Application of new energy-saving materials in construction engineering $[\mathrm{J}]$. Construction Engineering Technology and Design, 2019, (9): 3847. 